\title{
Infectivity of wild-type rubella virus in fibrochondrocyte cells
}

\section{Infectividade do vírus selvagem da rubéola em células de fibrocondrócitos}

Cristina A. Figueiredo; Maria I. Oliveira; Ana M. S. Afonso; Suely P. Curti

\section{key words abstract}

This study describes the rapid growth of the rubella virus in samples of a primary fibrochondrocyte cell

Rubella virus culture with the development of a cytopathic effect (CPE), in response to infection by the rubella virus. The cells were isolated from the meniscus joint of a rabbit after enzymatic extraction and incubated at $37^{\circ} \mathrm{C}$

Isolation with a Dulbecco's modified Eagle's medium (DMEM), supplemented with $10 \%$ fetal calf serum. A total of six clinical samples from urine, blood and cerebrospinal fluid were inoculated in the fibrochondrocyte and the cell lines of the African green monkey kidney - ATCC CCL-81 (Vero). The fibrochondrocyte cell showed CPE after 24 hours and virus growth was confirmed by immunohistochemistry and Nested PCR. The cells inoculated with samples were examined by phase contrast microscopy and showed characteristic rounding, along with bipolar and multipolar cells. The infection curve increased during the five days of observation, showing that the titers in fibrochondrocyte cells were then higher than those observed in Vero cell lines.

Este trabalho descreve o rápido crescimento do vírus da rubéola em amostras clínicas em cultura primária de fibrocondrócitos com desenvolvimento de efeito citopático em resposta a infecção pelo vírus da rubéola. As células foram isoladas do menisco do joelho do coelho após extração enzimática e incubadas a $37^{\circ} \mathrm{C} \mathrm{em}$ meio DMEM suplementado com $10 \%$ de soro fetal bovino. Seis amostras clínicas de urina, sangue e liquor foram inoculadas na cultura primária de fibrocondrócitos e na linhagem Vero. As células de fibrocondrócitos apresentaram efeito citopático após 24 horas de incubação e o vírus foi detectado por imunoistoquímica e Nested PCR. As células infectadas apresentaram aspecto arredondado, com formação de alguns prolongamentos citoplasmáticos $e$ sincícios, produzindo células multinucleadas. A curva de crescimento da infecciosidade do vírus foi mais alta quando comparada com a linhagem celular Vero.

\section{unitermos}

Fibrocondrócitos

Vírus da rubéola

Isolamento 


\section{Introduction}

The menisci of the knee are semilunar, fibrocartilaginous elements situated between the femoral condyles and tibial plateaus. The fibrocartilage consists of cells (fibrochondrocytes) surrounded by an abundant extracellular matrix ${ }^{(14,18,19)}$. Two populations of fibrochondrocytes can be discerned at both the light and electron microscopic levels, both resembling typical chondrocytes ${ }^{(9,10)}$. Unlike fibroblasts, the fibrochondrocytes are either round or oval, and are situated in lacunae ${ }^{(11)}$.

Rheumatoid arthritis (RA) is the most common type of inflammatory arthritis, affecting about $1 \%$ of the general population worldwide. The etiology of RA remains a mystery, but a variety of studies suggest that a blend of environmental and genetic factors is responsible. The contribution of either one is necessary but not sufficient for full expression of the disease. Extensive research in this regard has been negative. Similarly, considerable attention has been directed at the potential role for viruses in arthritis and the possible cause of infection, including the rubella virus $(3,7,8)$.

Rubella virus is a RNA virus which, most commonly, only causes an acute, mild systemic illness characterized by fever and exanthema ${ }^{(2)}$. However, the association of rubella virus with acute, transient joint manifestations, after both natural infection and vaccination, has been recognized for many years ${ }^{(4,16,17)}$.

The present study showed the rapid growth of the rubella virus in fibrochondrocyte cells isolated from rabbit knee-joints with the development of cytopathic effects in response to infection by rubella virus. The rubella virus isolated from the samples were titered simultaneously in the African green monkey kidney - ATCC CCL-81 (Vero) cells and fibrochondrocyte cells.

\section{Materials and methods}

\section{Rubella virus positive samples}

The six positive rubella virus clinical samples (of blood, urine and cerebrospinal fluid) used in this study were obtained during screening for rubella or measles virus. Two samples of the peripheral blood lymphocytes were separated from heparinized blood with ficoll-hypaque gradients and suspended in Dulbecco's modified Eagle's medium (DMEM - Gibco, Grand Island, NY, USA) supplemented by $2 \%$ fetal calf serum (FCS). The samples were stored at $-70^{\circ} \mathrm{C}$ until further process.

\section{Primary cell culture}

The knee joints of male and female New Zealand white rabbits of six months of age were exposed to aseptic conditions. The lateral and medial menisci were surgically removed from knee-joints and rinsed in saline solution, $\mathrm{pH} 7.5$, containing $40 \mu \mathrm{g} / \mathrm{mL}$ of gentamicin (Schering, Corp.).Then, the menisci were placed in Petri dishes containing DMEM with $10 \%$ FCS, $2 \mathrm{mM}$ L-glutamine and $40 \mu \mathrm{g} / \mathrm{mL}$ gentamicin (Schering, Corp.) The cells were isolated by sequential treatment of the minced tissue with $2 \mathrm{mg} / \mathrm{mL}$ clostridial collagenase (Gibco, Grand Island, NY, USA) in DMEM with $10 \%$ FCS, $2 \mathrm{mM}$ L-glutamine and $40 \mu \mathrm{g} / \mathrm{mL}$ gentamicin (Schering, Corp.) to release the cells from the tissue. The cells were then centrifugated at 250x $g$ for ten minutes and washed with DMEM containing $10 \%$ FCS. Cell number was determined using a hematocytometric chamber, and cell viability was assessed by trypan blue $(0.1 \%)$ exclusion. Primary cultures were started by inoculating $5 \times 10^{5}$ cells $/ \mathrm{mL}$ in T25 plastic culture flasks containing $10 \mathrm{~mL}$ of DMEM supplemented with $10 \%$ FCS and were maintained at $37^{\circ} \mathrm{C}$. The cells were submitted to incubation at $37^{\circ} \mathrm{C}$ in a water-saturated atmosphere with $5 \% \mathrm{CO}_{2}$. The first passage was established from cells obtained by trypsin treatment of confluent primary cultures and fibrochondrocytes were split 1:2 with DMEM supplemented as described above.

Primary and first passage cultures were used in this study because of the cells retaining many of their in vivo phenotypic characteristics.

\section{Virus growth}

The cell line of the African green monkey kidney - ATCC CCL-81 (Vero) and fibrochondrocyte cells containing $1 \times 10^{6}$ cells $/ \mathrm{mL}$ were grown in T25 flasks in DMEM supplemented with $10 \%$ FCS, $20 \mathrm{mM}$ L-glutamine. The confluent cells were inoculated with $0.5 \mathrm{~mL}$ RA $27 / 3$ virus strain (Meruvax II, Merck, Sharp and Dohme) and $0.5 \mathrm{~mL}$ of each sample for one hour at room temperature. After one hour of adsorption, each cell culture received $5 \mathrm{~mL}$ of medium with $2 \%$ FCS and were incubated at $37^{\circ} \mathrm{C}$. The medium was replaced every three days. Cell cultures were observed for CPE daily during seven days. After this time period, the cells were harvested, frozen, and thawed once, and the clarified supernatant was stored in aliquots at $-70^{\circ} \mathrm{C}$. Uninfected cultures were also prepared and treated identically.

\section{Virus stock}

The rubella virus RA 27/3 strain (Meruvax II, Merck, Sharp and Dohme) and positive rubella samples were grown 
in Vero and fibrochondrocyte cells. The cells containing 2 $\times 10^{6}$ cells were grown in T25 flasks in DMEM with $10 \%$ FCS and infected with $0.5 \mathrm{~mL}$ of the RA $27 / 3$ virus strain and positive rubella samples. The cells were maintained in DMEM supplemented with $2 \%$ fetal calf serum, $20 \mathrm{mM}$ L-glutamine and $0.1 \%$ gentamicin. For the virus stock, three passages were performed on cell cultures.

\section{Titration of virus}

The first passage Vero cell line and fibrochondrocyte cells $\left(1 \times 10^{5}\right.$ cells $\left./ \mathrm{mL}\right)$ were grown in 24 well plates in DMEM, supplemented with $2 \mathrm{mM}$ L-glutamine and $10 \%$ FCS. Plates were incubated at $37^{\circ} \mathrm{C}$ in a humidified $5 \% \mathrm{CO}_{2}$ atmosphere. A serial tenfold dilution of the rubella virus (RA 27/3 strain and positive rubella samples) were prepared in DMEM. The confluent cells were inoculated with $200 \mu \mathrm{L}$ of the virus dilutions in quadruplicates, for each different cell lines. After one hour of adsorption at room temperature, each well received $2 \mathrm{~mL}$ of medium DMEM with $2 \%$ FCS. Uninfected cultures were also prepared and treated identically as controls. Plate cultures were observed for CPE daily during seven days, when the test was concluded. Fifty per cent infectivity end points were calculated by the method of Karber ${ }^{(12)}$. All titers are given as $\log 10 \mathrm{TCID}_{50}$ per $.0 .1 \mathrm{~mL}$ of virus.

\section{Optic microscopy}

The infected and uninfected fibrochondrocyte cells were cultivated on coverslips for staining with blue toluidine and hematoxylin-eosin (H\&E).The cells were rinsed with cacodylate buffer and sucrose $0.2 \mathrm{M}$ for $30 \mathrm{~min}$ at room temperature. The cultures were fixed in situ with $1 \%$ glutaraldehyde in $0.15 \mathrm{M}$ phosphate buffer at $\mathrm{pH} 7.2$ for one hour at $4^{\circ} \mathrm{C}$. After being rinsed twice with cacodylate buffer and stained directly with toluidine blue and H\&E the cells were examined by light microscopy and photographed.

The blue toluidine specifies fibrocartilage and H\&E stain makes CPE evident.

\section{Immunoperoxidase staining of RV antigen}

Fibrochondrocyte cells in first passage were grown in micro tissue culture chamber slides (Nunc Inc., Naperville, IL ) at a concentration of $1 \times 10^{5}$ cells $/ \mathrm{mL}$ and incubated at $37^{\circ} \mathrm{C}$ in a humidified $5 \% \mathrm{CO}_{2}$ atmosphere, then the cultures confluent monolayers were infected with 0.01 moi rubella virus isolated from urine and RA $27 / 3$ strain. After one hour of adsorption at room temperature, $1 \mathrm{~mL}$ of maintenance medium was added. Uninfected cells were included as negative controls.
After three days, the cell monolayers were rinsed with phosphate-buffered saline (PBS) and fixed with $4 \%$ paraformaldehyde in phosphate buffer. The cells were then treated with $1.8 \%$ hydrogen peroxide in methanol to remove endogenous peroxidase activity. Indirect immunoperoxidase staining was carried out with monoclonal antibody to rubella virus (Chemicon, USA) followed by incubation with peroxidase-labelled goat anti-mouse IgG. Both primary and secondary antibody incubations were carried out at room temperature for one hour. The peroxidase substrate 3,3' diaminobenzidine tetrahydrochloride (Sigma, USA) was used as chromogen. After counterstaining in $\mathrm{H} \& \mathrm{E}$, the cells were examined in a light microscope. Immunostained negative controls were included by replacing the primary antibody with PBS.

\section{Nested PCR assay}

The cultures inoculated with samples - peripheral blood lymphocytes, urine and cerebrospinal fluid - were individually snap-frozen in plastic vials, stored at $-70^{\circ} \mathrm{C}$. RNA was extracted from the entire cell pellet by the guanidinium isothiocyanate method and submitted reverse transcriptase-PCR (RT-PCR) followed by Nested PCR as described by Best(2).

\section{Results}

The fibrochondrocyte cells maintained their capacity to form chondro-like structures in vitro and maintained tissue organization. The cells morphologically consisted of elongated fibroblast-like cells, which form good, wellmaintained monolayers (Figure 1A).

The cells inoculated with the RA/27-3 strain and the samples were examined by phase-contrast microscopy; they revealed increased cellular refractability and rounding of the infected cells. The first morphological changes were observed in 24 hours after inoculation of the rubella virus and they spread to complete infection by the seventh day. The manifestations of the infection by rubella virus were the vacuolization of the cytoplasm at the cell poles and the contraction of the cytoplasm around the altered nucleus (Figure 1B). The infected cells, after seven days, appeared rounded (Figure 1B). The CPE is usually seen at the top or margins of the cell sheet, and in some concentration in certain areas. It is to be emphasized that in the process, the great majority of remaining cells attach themselves to the flask. The immunoperoxidase staining of fibrochondrocyte cells was made after three days, the cells being inoculated with RA $27 / 3$ and rubella virus isolated from urine. The cells 
infected with the sample show antigens appearing as a dark-brown stain in the cells. Close to the nucleus, there was a circular shape seen with a contraction of the cytoplasm around the altered nucleus (Figure 1C).

Titrations were done using tenfold dilutions of the virus inoculated into plate cultures/dilutions with the same set of dilutions used for all two cell types. During the growth of the virus, medium DMEM only was used to maintain the cultures and no fluid changes were made. The infection curve increased during the five days of observation, and showed that the titers in the fibrochondrocyte cells were higher than those observed in the Vero cell line. The titers were: Vero cells: $10^{5,51}$ (cerebrospinal fluid), $10^{5,90}$ (blood), $10^{6,05}$ (urine) $\mathrm{TCID}_{50} / 0.1 \mathrm{~mL}$; and fibrochondrocytes cells: $10^{6,45}$ (cerebrospinal fluid), 106,92 (blood), 107,05 (urine) $\mathrm{TCID}_{50} / 0.1 \mathrm{~mL}$ (Figures $\mathbf{2 A}$ and $\mathbf{B}$ ).

The viral genome was extracted from fibrochondrocytes inoculated with samples and RA $27 / 3$ strain after four days of the incubation. The viral genome was amplified by Nested PCR product visualized in $2 \%$ agarose stained with ethidium bromide, and had an expected length of 243 base pairs.

All stock primary cultures maintained in our laboratory were checked from time to time for the presence of mycoplasma and other contaminants and the results were negative. The preservation of fibrochondrocyte cells was possible by freezing in liquid nitrogen. The cells were frozen

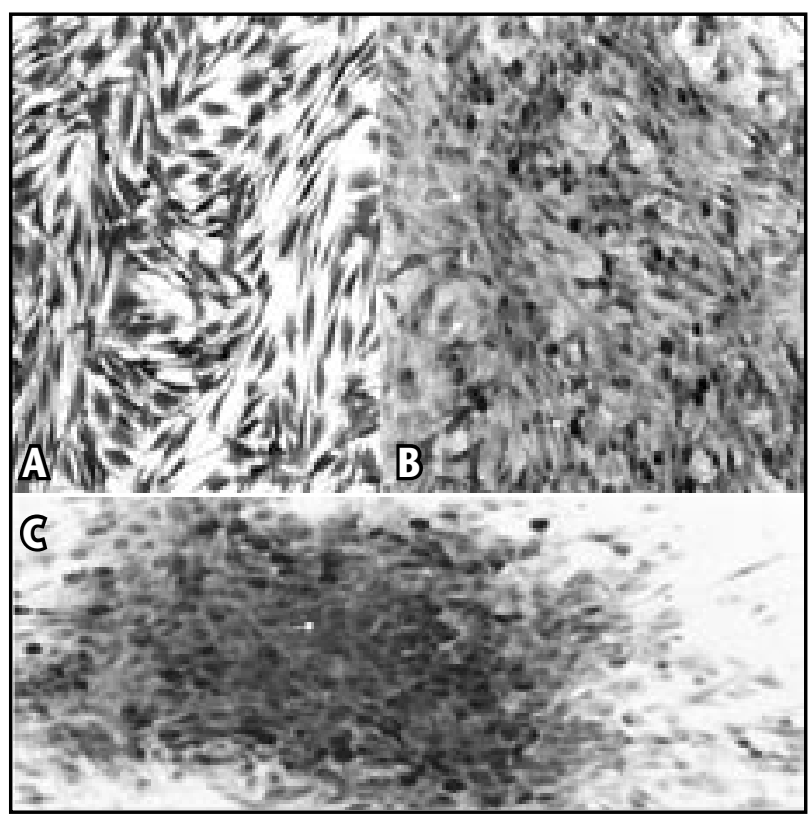

Figure 1 - Cytopathic effect of rubella virus in fibrochondrocyte. A: Uninfected; $B$ : Cells infected after 5 days with positive rubella sample (urine). Observe the cytopathic effect is characterized by a formation of foci consisting of small, circular cells, (100x); C: Immunoperoxidase staining fibrochondrocyte cells infected for 3 days with urine sample. Note viral antigens appear as a dark brown stain in the cells. Note circular cells. (100x)

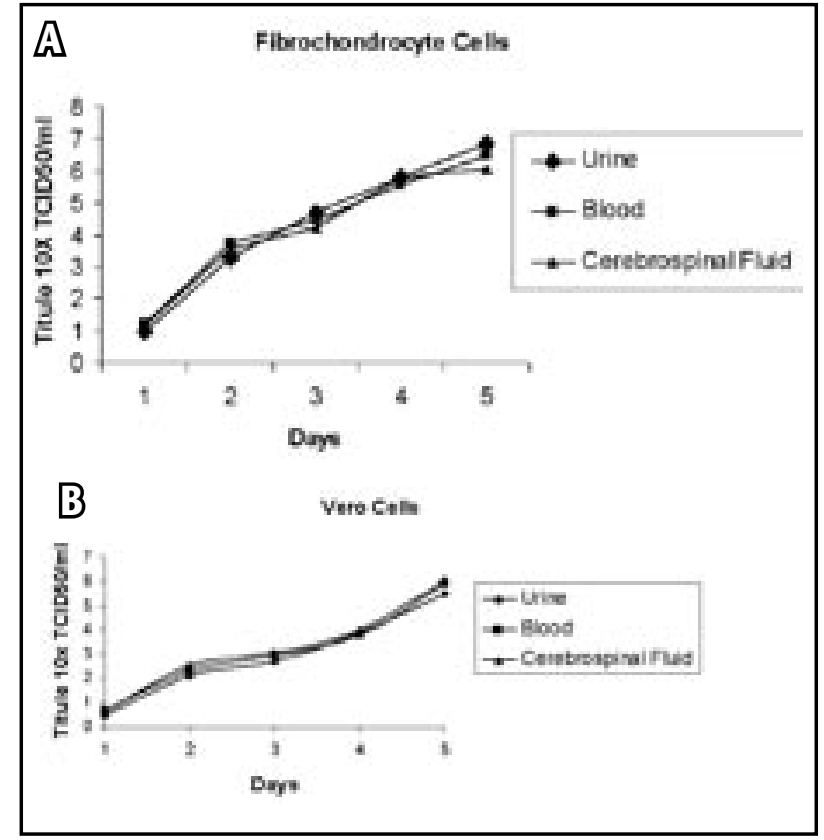

Figure 2 - A: Curve of the increased infectivity of fibrochondrocyte cells infected with samples (urine, blood and cerebrospinal fluid) and observed during 5 days; $B$ : Vero cells infected with the same samples

in the presence of $10 \%$ fetal calf serum (FCS) plus $10 \%$ DMSO. Various successful recoveries from liquid nitrogen storage have been made in our laboratory and we have obtained satisfactory results.

\section{Discussion}

Rubella virus is the causative agent of the disease commonly known as German measles. However, rubella can cause complications with transient joint involvement such as arthritis and arthralgia. Interestingly, these symptoms are more prevalent and severe in RV-infected women than in RV-infected men ${ }^{(4,15)}$. The frequency with which rubella virus infects joints during acute infection and the percentage of these joint infections that result in arthritis are unknown.

RV infects many culture cell lines but can establish productive infection only in a limited number of cell lines. The cell lines most used for virus growth are $\mathrm{RK}_{13^{\prime}}$ SIRC and $\operatorname{Vero}^{(2,20)}$.

The present report describes the growth and titration of the rubella virus isolated in samples of fibrochondrocyte cells in comparison the Vero cell line. The fibrochondrocyte cells in vitro form a three-dimensional, multilayered structure that resembles a cartilaginous tissue ${ }^{(6,1)}$.

These cells infected with rubella virus induced detectable CPE after 24 hours of the inoculation and are easily visualized in the light microscope and after immunoperoxidase 
staining. Reports by Chantler and Cunningham described rubella virus in human chondrocyte and synovial cells showing detectable CPE and these cells have been shown to be as effective for study of rubella virus ${ }^{(3,5)}$.

The growth curve for the rubella virus in fibrochondrocyte cells was higher compared with the Vero cell line. This is important because it shows that cells can lose susceptibility for virus while rubella virus is replicating.

The association of rubella virus with acute, transient joint manifestations, after both natural infection and vaccination, has been recognized for many years ${ }^{(4,16,17)}$, but the search for persistent rubella virus isolation in subjects with chronic joint symptoms following rubella or rubella immunization has been unsuccessful ${ }^{(8,17)}$.

Recently, Lund demonstrated that the growth of rubella virus strains vary in their abilities to replicate and persists in cell cultures derived from human joint tissues, and that this arthrotropism appears to be linked to their association with joint symptoms in vivo(13).

These findings indicate that fibrochondrocyte cells could be a useful tool to investigate the arthrotropism of different RV isolates. The fibrochondrocyte cultures have the advantage of being easier to manipulate and providing greater consistency for comparative experimentation than organ.

\section{References}

I.ARAÚJO,V. G. et al. In vitro rapid organization of rabbit meniscus fibrochondrocytes into chondro-like tissue structures. J Submicrosc Cytol Pathol, v. 34, n. 3, p. 335-43, 2002.

2. BEST, J. M.; O'SHEA, S. Rubella virus. In: LENNETTE, E.H.; SCHIMIDIT, N.J.(Eds.). Diagnostic procedures for viral, rickettsial and chlamydial infections. 7. ed. Washington, DC: American Public Health Associations, 1995. p. 583.

3. CHANTLER, J. K. et al. Characterization of rubella virus strain differences associated with attenuation. Intervirology, v. 36, p. 225-36, 1993

4. COOPER, L. Z. et al. Transient arthritis after rubella vaccination. Am J Dis Child, v. I I 8, p. 218-25, 1969.

5. CUNNINGHAM, A. L. et al. Persistent rubella virus infection of human synovial cell cultured in vitro. I Infec Dis, v. I 5 |, p. 638-45, 1985

6. FIGUEIREDO, C.A. Avaliação morfológica de fibrocondrócitos em cultura e detecção bioquímica dos proteoglicanos sintetizados. São Paulo, 1996. Dissertação (mestrado em Bioquímica). Universidade Federal de São Paulo (Unifesp).

7. FORD, D. K.; TINGLE, A. J:; CHANTLER, J. K. Rubella arthritis. In: ESPINOZA, L.; ALARCON, G.; ARNETT, F.; GOLDENBERG, D. (Eds.). Infections in the rheumatic diseases. New York: Grune \& Stratton, 1988. Cap. 14 p. 103-8.

8. FRENKEL, L. M. et al. A search for persistent rubella virus infection in persons with chronic symptoms after rubella and rubella immunization and in patients with juvenile rheumatoid arthritis. Clin Infect Dis, v. 22, p. 287-94, 1996.

9. GHADIALLY,F.N. et al. Ultrastructure of rabbit semilunar cartilage. J Anat, v. 125, p. 499, 1978

10. GHOSH, P. et al. Variations in collagen, noncollagenous proteins, and hexosamine in menisci derived from osteoarthritic and rheumatoid arthritic knee joints. J Rheumatol, v. 2, p. 100,1975

I I. GHOSH, P. et al. The knee joint meniscus: a fibrocartilage of some distinction. Clin Orthop, v. 224, p. 52-6, 1987
12.KARBER, G. Beitrag zur kolledtiven behandlung pharmakologischer reihenversuche. Arch Exp Pathol Pharmakol, v. I62, p. 480-3, 1931.

I 3. LUND, K. D.; CHANTLER, J. K. Mapping of genetic determinants of rubella virus associated with growth in joint tissue. Journal of Virology, v. 74, n. 2, p. 796-804, 2000.

14. McDEVITT, C. A.; WEBBER, J.R. The ultrastructure and biochemistry of meniscal cartilage. Clinical Orthopaedics and Related Research, v. 252, p. 8-18, 1990.

I5. MIKI, N. P. H.; CHANTLER, J. K. Differential ability of wild-type \& vaccine strains of rubella virus to replicate and persist in human joint tissue. Clin Exp Rheumatol, v. 10, p. 3-12, 1992

16.TINGLE,A. J. et al. Postpartum rubella immunisation: association with development of prolonged arthritis, neurological sequelae, and chronic rubella viremia. J Infect Dis, v. 152 p. 606-12, 1985.

17. TINGLE, A. J. et al. Rubella-associated arthritis, comparative study of joint manifestations associated with natural rubella infection and Ra 27/3 immunisation. Annals of the Rheumatic Diseases, v. 45, p. 1 1 0-4, 1986.

I8.WEBBER, R.J. et al. Cell culture of rabbit meniscal fibrochondrocytes: proliferative and synthetic response to growth factors and ascorbate.J Orthop Res, v. 3, p. 36, 1985.

19. WEBBER, R. J. et al. In vitro cell proliferation and proteoglycan synthesis of rabbit meniscal fibrochondrocytes as a function of age and sex. Arthritis and Rheumatism, v. 8, p. 1010-6, 1986.

20. WOLINSKY, J. S. Rubella. In: FIELDS, B. N.; KNIPE, D. M. (Eds.). Virology. New York: Raven Press, 1990. p. 8I5-38.

\section{Mailing address}

Cristina Adelaide Figueiredo Instituto Adolfo Lutz Serviço de Virologia/Divisão de Biologia Médica Av. Dr. Arnaldo, 355 CEP 01246-902 - São Paulo-SP e-mail: cfiguei@@ial.sp.gov.br 